\title{
REVIEW ESSAY: HUMAN RIGHTS IN THE 'WAR ON TERROR'
}

\author{
Alberto Costi*
}

Richard Ashby Wilson (ed) Human Rights in the 'War on Terror' (Cambridge University Press, Cambridge, 2005) (347 pages).

Since the terrorist attacks in the United States on 11 September 2001 (hereafter 9/11), in Madrid on 11 March 2004, in London on 7 July 2005 and, closer to home, the Bali bombings of October 2002 and 2005, terrorism has metamorphosed the global security environment. States have been forced to redefine the nature of terrorism and to reassess the political, military and legal means necessary to protect the State, its institutions and its citizens.

In reaction to perceived threats to national security, the international community has continued to negotiate an extensive range of international measures to counter terrorism and related activities. ${ }^{1}$ Moreover, some States have sought to question existing norms of international law and have even been willing to act unilaterally to defeat terrorism. At the national level, governments have been equally active, adopting domestic legislation designed to protect the vital interests of the State. ${ }^{2}$ This

* Senior Lecturer, Faculty of Law, Victoria University of Wellington.

1 Soon after the tragic events of 9/11, the United Nations Security Council unanimously adopted Resolution 1373, which amongst other things imposes an obligation on all member States to criminalise assistance for terrorist activities, deny financial support and safe haven to terrorists and share information about groups planning terrorist attacks: see UNSC Resolution 1373 (28 September 2001) S/RES/1373/2001, para 1. A 15member Counter-Terrorism Committee (CTC) was also established to monitor implementation of the Resolution. Other recent initiatives at the Security Council have included the creation of the CounterTerrorism Committee Executive Directorate to provide the CTC with expert advice on all areas covered by Resolution 1373: see UNSC Resolution 1535 (26 March 2004) S/RES/1535/2004. At the World Summit at the United Nations in September 2005, the Security Council - meeting at the level of Heads of States or Government - adopted a resolution concerning incitement to commit acts of terrorism and the obligation of all member States to comply with international human rights laws: UNSC Resolution 1624 (14 September 2005) S/RES/1624/2005.

2 In New Zealand, for instance, the Terrorism Suppression Act 2002 (TSA) (which incidentally had its origins in the pre-9/11 Terrorism (Bombings and Financing) Bill introduced in April 2001) was enacted in October 2002, serving as New Zealand's first ever comprehensive counter-terrorism scheme. The TSA, which has since been amended, ambitiously provides a definition of a terrorist act, criminalises terrorist activities, 
effervescence of domestic and international actions raises new challenges for orthodox tenets of international law, tests traditional alliances and threatens long-established concepts of civil liberties and human rights.

Ironically, this "age of terror" follows an era full of promises that was the 1990s. The end of the Cold War saw the walls of a bipolarised international community crumble and a new multilateral strategy emerge to tackle human rights challenges, not only within the forum of the United Nations (UN) but also at the regional level. The asymmetrical responses to the terrible atrocities in Rwanda, Somalia, East Timor and the former Yugoslavia led some commentators to wonder whether we were witnessing a new world order or disorder. ${ }^{3}$ The thaw in East-West relations was not yet complete when a new threat towards bipolarisation emerged from the shadows of the disintegrating twin towers of the World Trade Center in New York City. From the celebrated words of President Bush that "you are either with us or against us", ${ }^{4}$ to the formulation of a national security strategy and the questioning of multilateral institutions, the "war on terror", at the international level, has aimed at testing the boundaries of international law and has put security at the top of the global agenda. At the domestic level, the "war on terror" opened a debate that casts doubt on whether human rights and security can work hand in hand and in fact wonders how many human rights - and whose human rights - we can afford to respect.

These issues were the focus of a conference held exactly three years after the events of 9/11, from which the book Human Rights in the 'War on Terror', edited by Richard Ashby Wilson, emanates. ${ }^{5}$ Bringing together a stellar cast of human rights scholars, international lawyers, policymakers and activists, the conference looked at the place of human rights in the international political order, not only as a consequence of 9/11, but also in the light of the war on terror, the Iraqi invasion of March 2003, the detention of alleged terrorists at Guantanamo Bay and the decisions of the Supreme Court of the United States relating to their detention in Hamdiv Rumsfeld, Rumsfeld v

outlines criminal penalties for the commission of terrorist activities and sets forth procedures for the designation of terrorist entities.

3 See, for instance, Brad Roberts (ed) Order and Disorder after the Cold War: A Washington Quarterly Reader (Washington Quarterly Readers, Washington, DC, 1995); Robert B Oakley, Michael J Dziedzic and Eliot M Goldberg (eds) Policing the New World Disorder: Peace Operations and Public Security (National Defense University Press, Washington, DC, 1998); Joseph J Sisco "From World Disorder to a Reshaped Global Order: Myth or a Possible Opportunity?" (2002) 13 Mediterranean Quarterly 1. For an interesting discussion of the implications of the Iraqi crisis on the coherence of the international legal order, see Campbell McLachlan "After Baghdad: Conflict or Coherence in International Law?" (2003) 1 NZJPIL 25.

4 CNN "You Are Either With Us Or Against Us" (6 November 2001) <http://www.cnn.com> (last accessed 1 September 2006).

5 Human Rights in an Age of Terrorism Conference (9-11 September 2004) Human Rights Institute, University of Connecticut. 
Padilla and Rasul $v$ Bush. ${ }^{6}$ These insightful contributions aimed at reconciling human rights and security imperatives in the post-9/11 world form the basis of the book's central argument as conveyed by Richard Wilson in his introduction. ${ }^{7}$

Library shelves are replete with books examining 9/11 from various angles and critics might ask whether we need yet another assessment of the war on terror. That would not render justice to the idea behind the book, "to evaluate counter-terrorist policies since 9/11" but with a view "to develop a counter-strategy which takes human rights seriously." ${ }^{8}$ In other words, the book places itself squarely within some of the main current debates surrounding the war on terror in which some of the contributors have been very much involved: disputes between the apostles and opponents of the intervention in Iraq; differences of opinion among human rights proponents favouring a universal protection and those doubting their absolute character in times of crisis. These discussions are useful but they have blurred the line between liberty and security.

The premise of the book is innovative. Instead of polarising views around an absolutist defence of human rights, the contributions recognise that: ${ }^{9}$

$[\mathrm{H}]$ uman rights matter because they are an indispensable component of the liberal democratic politics required in emergency situations, a politics which insists upon the importance of individual rights, the separation of powers and a systematic review of executive power by the judicial and legislative branches.

One might disagree with Richard Wilson as to whether the war on terror really fulfils the condition of an "emergency", at least as we understand it in the context of human rights instruments. Nevertheless, no one will dispute the view that derogation from human rights in times of emergency is not to be presumed, an idea colourfully expressed by Judge O'Connor in Hamdi v Rumsfeld that even a state of war does not translate into "a blank check for the President". ${ }^{10}$

Wilson introduces the sixteen contributions that form the core of this book, dividing them loosely into five themes straddling 9/11: the urge of powerful States to use human rights as a tool of international affairs in the euphoria of the 1990s; the challenges the Al Qaeda attacks posed to State sovereignty and to traditional international relations in the new millennium; the case in favour of the war on terror; the arguments against it; and, finally, the impact of the war on terror on matters of

6 Hamdi v Rumsfeld (2004) 124 S Ct 2633; Rumsfeld v Padilla (2004) 124 S Ct 2711; Rasul v Bush (2004) 124 S Ct 2686.

7 Richard Ashby Wilson "Human Rights in the 'War on Terror"' in Richard Ashby Wilson (ed) Human Rights in the 'War on Terror' (Cambridge University Press, Cambridge, 2005).

8 Wilson, above n 7, 2 .

9 Wilson, above n 7, 3 .

10 Hamdi v Rumsfeld, above n 6, 2650 O'Connor J. 
national and transnational governance, especially the constraints on civil liberties in the United States. It is not surprising, under these conditions, that human rights became a means to an end in relation to the "coalition" intervention in Iraq in 2003. Moreover, the curtailment of human rights and civil liberties saw strange bedfellows working together officially and covertly. This is best exemplified by the rendition in 2003 of a Canadian citizen by the United States to Syria - a country that is usually criticised by the United States for its appalling human rights record and active support of terrorism - for "robust" interrogation on allegations of his possible links to Al Qaeda. ${ }^{11}$

According to this reviewer, the book advances four main propositions. First, it challenges the view that terrorism is a novel problem (even if the expression "war on terror" might be) requiring exceptional solutions. The problem, it seems, has been the limited success both nationally and internationally in finding the right strategy to combat this social phenomenon. Second, the book shows the limits of unilateralism or some form of "minilateralism", as opposed to multilateralism, in managing globally the war on terror. In particular, the danger of interventionist policies that only pay lip service to liberty and security is that they always open the door to double standards and recriminations. Third, it highlights the impact of the war on terror on human rights domestically and the potential use of an agenda of security over liberty by governments wishing to control their citizens ever more tightly. The possible diminution of legal protection for alleged terrorists or for those individuals corresponding to some racial profiling springs to mind. Surveillance of lawabiding citizens reminiscent of the McCarthy era is another danger lurking around the corner with legal instruments such as the USA Patriot Act. ${ }^{12}$ Finally, the book calls for an examination of terrorism in context. Terrorism might call for restrictions to human rights. Still, these restrictions are best addressed through the traditional analysis of human rights. To combat terrorism, its root causes must be tackled and efforts made to eliminate them. It is essential to generate a sound debate on liberty and security so as to design appropriate policies that place human rights at the forefront. It is crucial, therefore, to educate citizens about human rights for them to remain vigilant and critically assess State restrictions that appear arbitrary and erode respect for the rule of law and due process.

11 See, for instance, David Weissbrodt and Amy Bergquist "Extraordinary Renditions: A Human Rights Analysis" (2006) 19 Harv Hum Rights J 123, 146. The citizen in question, Maher Arar, was eventually freed and the Canadian government set up a commission of inquiry to look into allegations of torture perpetrated by Syrian officials following his extraordinary rendition by United States officials: Harold Hongju Koh "Can the President be Torturer in Chief?" (2006) 81 Ind L J 1145, 1149 n 15. A three-volume report looking at the actions of Canadian officials in relation to Maher Arar has been recently released. It found that there was no evidence that he was a threat to the security of Canada or that he committed any offence: Commission of Inquiry into the Actions of Canadian Officials in Relation to Maher Arar Report of the Events Relating to Maher Arar - Analysis and Recommendations (Public Works and Government Services Canada, Ottawa, 2006), available at $<$ http://www.ararcommission.ca $>$ (last accessed 20 September 2006).

12 Uniting and Strengthening America by Providing Appropriate Tools Required to Intercept and Obstruct Terrorism Act (USA Patriot Act) of 2001, Pub L No 107-56, 115 Stat 272. 
The chapters in this book fall more or less under these four main clusters. This is the format adopted in the remainder of this essay to facilitate the discussion of the book.

The first cluster includes Richard Wilson's introductory chapter and the chapters of Michael Freeman and Fernando Tesón. Their contributions examine how the development of the human rights movement following the end of the Cold War and the momentum gathered by the war on terror in the aftermath of 9/11 have influenced the way terrorism is addressed. Wilson and Freeman analyse terrorism and threats to State security through the Ages. Freeman, in particular, reminds us that debates about rights in times of emergency go back to the origins of Western democracy, starting with the tumultuous years of civil war, interregnum and restoration in Britain during the $17^{\text {th }}$ century. ${ }^{13}$

Wilson and Freeman accurately point out that although terrorism is an age-old problem, new solutions are necessary if counter-terrorism operations are to succeed. Both stress the failures of national governments and international institutions in eradicating terrorism in the late 1990s. Rather than simply blaming the Bush administration for curtailing rights to preserve security, Wilson rightly questions whether existing global and regional institutions and instruments are apt to deal with and contain contemporary global terrorism. ${ }^{14}$ Freeman even goes further, questioning whether the UN is ill-equipped to address terrorism and asserting that other organisations, such as the World Trade Organization, might actually fuel the root causes of terrorism. ${ }^{15}$ Wilson calls for a reconceptualisation of these international agencies to meet the threat of terrorism by preserving the importance of a multilateral approach to global problems. Freeman's contribution leads the reader to wonder how democracies, individually and jointly, should respond to security threats. This is where Fernando Tesón enters the frame, with a challenging contribution threading a fine line between liberty and security. Tesón puts forward a conceptual argument: "restrictions on liberty are justified, if they are, only by the need to preserve liberty itself and not by other values such as order or security". ${ }^{16}$ Applying it to $9 / 11$, he concludes that even if temporary restrictions to individual

13 Michael Freeman "Order, Rights and Threats: Terrorism and Global Justice" in Richard Ashby Wilson (ed) Human Rights in the 'War on Terror' (Cambridge University Press, Cambridge, 2005) 37, 39-40. Geoffrey Robertson, in a later chapter, also refers to the dilemmas of security and liberty in the context of restoration of the monarchy in England, where the new government was confronted with the problem of a significant number of republican prisoners who could not be put on trial - because they attracted considerable public sympathy - or be detained indefinitely because of habeas corpus: Geoffrey Robertson "Fair Trials for Terrorists?" in Richard Ashby Wilson (ed) Human Rights in the 'War on Terror' (Cambridge University Press, Cambridge, 2005) 169, 171-173.

14 Wilson, above $\mathrm{n} 7,4-5$. He refers to the fact that international terrorism is not a crime over which the International Criminal Court was granted jurisdiction under the 1998 Rome Statute (at 7).

15 Freeman, above n 13, $42-43$ and 54.

16 Fernando Tesón "Liberal Security" in Richard Ashby Wilson (ed) Human Rights in the 'War on Terror' (Cambridge University Press, Cambridge, 2005) 57, 58. 
freedoms might be necessary in response to such a threat, "a properly tailored fight against terror is a fight for human rights, not antithetical to them". ${ }^{17}$ This approach challenges the position defended by a another leading human rights scholar, Michael Ignatieff, who conceded that liberal democracies have the right to defend their security and integrity even if in the process they might breach some of the basic rights they would otherwise normally protect. ${ }^{18}$ Eerily, Ignatieff's position echoes the view expressed by the former Chief Justice of the United States Supreme Court, William Rehnquist, who wrote that in wartime, the balance between freedom and order "shifts in favor of order - in favor of the government's ability to deal with conditions that threaten the national well-being." ${ }^{19}$ Another interesting aspect of Tesón's contribution is his definition of what represents a security threat. Having grown up in Argentina at a time when dictatorial regimes happily invoked national security to achieve dubious ends, Tesón is not afraid of distinguishing between conduct that threatens democratic society and its related institutions (which authorities should be entitled to tackle through specific legislation) and anti-democratic behaviour such as freedom of speech falling short of a threat, for which standard criminal law instruments suffice. ${ }^{20}$ In other terms, the $9 / 11$ attacks might have justified some restrictions to liberty precisely because they threatened liberty. This is a courageous proposition, at a time where nuance and subtlety seem to have eluded American politics and academics seem weary of opinions that could be misconstrued. As a critique, the objective of repelling terrorism as part of a struggle for human rights remains a very subjective proposition that could be misinterpreted, if not abused, by the authorities.

The second cluster builds upon the idea that the legitimacy of the State can only be maintained by the principles of freedom and rights and that the State is compelled to uphold these values on the international plane. The "coalition" intervention in Iraq in 2003 fuels the debate here. It is interesting that so many contributors chose to include Iraq in this discussion. It seems this inclusion gives credibility, perhaps inadvertently, to the argument that there was a link between Saddam Hussein's regime and Al Qaeda, even if the existence of such a link has now been categorically rejected, even by the Senate of the United States. ${ }^{21}$ Moreover, the case for intervening even on alleged humanitarian grounds remains weak in the absence of an international mandate. Thomas

17 Tesón, above n 16, 58.

18 Michael Ignatieff The Lesser Evil: Political Ethics in an Age of Terror (Princeton University Press, Princeton, 2004) 8-9.

19 William H Rehnquist All the Laws But One: Civil Liberties in Wartime (Alfred A Knopf, New York, 1998) 222.

20 Tesón, above n 16, 59.

21 United States Senate, Select Committee on Intelligence Report of the Select Committee on Intelligence on Postwar Findings About Iraq's WMD Programs and Links to Terrorism and How They Compare with Prewar Assessments Together with Additional Views (109 ${ }^{\text {th }}$ Congress, 2d session, 8 September 2006) 125126. 
Cushman argues the importance of going beyond the law where necessary. He acknowledges that the United States-led operation was "probably" illegal under the orthodox tenets of international law. ${ }^{22}$ However, the resolve of the Bush administration was rewarded by the overwhelming support of the Iraqi population and in the end the legitimisation of the operation by the UN Security Council. Figures are produced to highlight popular support for the intervention ridding Iraq of Saddam Hussein. ${ }^{23}$ No doubt, the decision of the Security Council to lift the economic sanctions imposed against Iraq ${ }^{24}$ marked the first step towards alleviating the suffering of ordinary Iraqis and showed the strong commitment of the Security Council members to put aside their differences to bring some stability to this country devastated by the scourge of three major conflicts in the past 25 years. It is easy with hindsight to criticise Cushman's argument, but the scenes of joy that followed the toppling of Saddam Hussein's statues in Baghdad could hardly have prepared us for the spiralling of violence that was to follow. To his credit, Cushman acknowledges the horrific criminal and sectarian violence crippling Baghdad and other areas of Iraq. Cushman, it is fair to say, is not isolated in his views, with a number of liberal thinkers, for instance Michael Ignatieff, defending that intervention. ${ }^{25}$

Support for an intervention falling short of the UN stamp of approval is strongly criticised by John Wallach, who states that Ignatieff's articulation of human rights as an "ethics of power" is something "that will be practiced at the expense of much democracy and many human rights". ${ }^{26}$ This danger is very well illustrated by Aryeh Neyer, who, ironically perhaps, begins his chapter by reminding the reader of the generally good record of present and past United States administrations in highlighting human rights abuses in other States, whether friendly or not. Neyer finds that, sadly, this good groundwork has been reduced to nothing by the Bush administration hammering home the belief that the security of the United States can only be achieved by the promotion of freedom and democracy in the Middle East and by what is happening in its own backyard at Guantanamo Bay. ${ }^{27}$

22 Thomas Cushman "The Human Rights Case for the War in Iraq: A Consequentialist View" in Richard Ashby Wilson (ed) Human Rights in the 'War on Terror' (Cambridge University Press, Cambridge, 2005) 78,78 .

23 Cushman, above n 22, 94-99.

24 UNSC Resolution 1483 (22 May 2003) S/RES/1483/2003.

25 Michael Ignatieff "The Burden" (5 January 2003) New York Times Magazine New York. A year later, he still defended his original position, brushing aside any second thoughts: Michael Ignatieff "The Year of Living Dangerously" (14 March 2004) New York Times Magazine New York 13.

26 John R Wallach "Human Rights as an Ethics of Power" in Richard Ashby Wilson (ed) Human Rights in the 'War on Terror' (Cambridge University Press, Cambridge, 2005) 108, 122. He is particularly critical of Ignatieff's support of the ethics of "the lesser evil" and his "elevation of 'security' to the principal political problem", as it condones "the discretionary judgment of rules" (at 123-124).

27 Aryeh Neyer "How Not to Promote Democracy and Human Rights" in Richard Ashby Wilson (ed) Human Rights in the 'War on Terror' (Cambridge University Press, Cambridge, 2005) 137, 138-141. 
He does acknowledge the fact that the promotion of freedom and democracy is crucial to the development of the region, a view that has also been advocated by the UN and by a number of local leaders. Unfortunately, he says, the United States' willingness to flex muscles and use military force as a tool of foreign policy has only met with contempt and has deprived the current administration of legitimacy in the Arab world, to the point that moderate leaders and intellectuals have had to distance themselves from this rhetoric as hindering their own efforts. ${ }^{28}$ Even more damaging has been the treatment of the detainees at Guantanamo Bay, which is worse than anyone could ever have expected, especially when compared to the way Great Britain, Spain, India and Israel have dealt with terrorism. ${ }^{29}$ Add to this the abuses committed at Abu Ghraib and the use of extraordinary renditions, and it is not difficult to understand why this affront to the rule of law feeds antiAmericanism around the world, weakens the language of human rights and sets a wrong precedent.

Returning to the legitimacy of the intervention in Iraq in March 2003, Kenneth Roth, the executive director of Human Rights Watch, argues that the coalition's operation failed to meet the test for a humanitarian intervention. First, the killings in Iraq at the time of the invasion were not of an exceptional nature that would justify such intervention. ${ }^{30}$ Second, military action was not the last reasonable option to stop Iraqi atrocities. ${ }^{31}$ Inspections were being carried out by the International Atomic Energy Agency regarding widespread claims of the presence of weapons of mass destruction that could be used by terrorist groups outside its borders and by Iraq against Israel and other Arab nations. It is unfortunate that the contributions of Roth and Cushman fail to analyse the intervention in Iraq through the lenses of the "responsibility to protect", a concept that since the intervention in Kosovo in 1999 has been widely discussed in both official and academic circles. Its adoption in the Outcome Document of the World Summit signed by the Head of States of all UN members in September 2005 is a further recognition of the need to challenge the traditional notion of non-intervention in the internal affairs of a sovereign State. ${ }^{32}$ There is a fine line between, on the one hand, a legitimate intervention by a State or a coalition of States within the borders of another sovereign State to protect basic human rights, and, on the other, a military operation aiming primarily at imposing a change of regime, with humanitarian grounds serving only as an alternative or subsidiary justification. Where does a strike to prevent the possible spread of terror beyond the borders fit in this spectrum? That question remains open to further debate.

28 Neyer, above n 27, 139.

29 Neyer, above $\mathrm{n} 27,140$.

30 Kenneth Roth "War in Iraq: Not a Humanitarian Intervention" in Richard Ashby Wilson (ed) Human Rights in the 'War on Terror' (Cambridge University Press, Cambridge, 2005) 143, 147-149.

31 Roth, above n 30, 149-150. He also casts doubt on the humanitarian character of the intervention (at 151152).

32 UNGA Resolution Adopted by the General Assembly: 2005 World Summit Outcome (24 October 2005) $\mathrm{A} / \mathrm{RES} / 60 / 1$, paras $138-140$. 
The third cluster addresses the effects of the war on terror on domestic policies. To start with, Richard Goldstone stresses the fact that terrorism is not a new phenomenon and highlights the threat that war can pose for human rights. He argues that the rule of law must never be jeopardised and that, in relation to Guantanamo Bay, the lack of respect for the Geneva Conventions might well return to haunt the United States in a future conflict. ${ }^{33} \mathrm{He}$ further observes with discomfort that other governments have since 9/11 taken repressive actions along the same trends as the United States. Probably the most important question he asks is whether it is "appropriate to wage a 'war' against terrorism". ${ }^{34}$ In fact, the following passage summarises well his views: ${ }^{35}$

Terrorism is unlikely ever to end, and formulating a policy based upon a model of 'war' is only

calculated to allow the government to regard anyone who opposes undemocratic means as unpatriotic. If

the government fails to act within the law, it undermines its democratic legitimacy, forfeits public

confidence, and damages respect for the criminal justice system.

Geoffrey Robertson looks at probably the most challenging question from the point of view of due process: "how to achieve fair trials for men and women who are demonized by the society from which their judges and jurors are drawn"? $?^{36}$ Terrorist labelling by authorities can be a major impediment to a fair trial and so can be the risk that a trial might give a platform to some unsavoury characters. Yet, Robertson puts on a strong argument defending the need for justice to be made, in conformity with "inherited Anglo-American traditions", that is, through a genuine adversary process determined by an independent judge. ${ }^{37}$ His chapter documents how some of the most important judicial guarantees developed in times of crisis in England. He further advocates the need for an international process, certainly based in part on his own expertise as an international judge and a long-time defender of human rights. More importantly, Robertson believes that putting a terrorist or a dictator on the stand will dissipate their cult status and will in fact expose the evidence, setting a proper public record of the atrocities committed. ${ }^{38}$ It can be added here that a criminal process creates a historical survey of events. Forgetting or playing down atrocities sends out a wrong message to those who might consider committing such crimes. This is illustrated by the welldocumented response of Hitler to the question whether the planned mass execution of Jews, Slavs and many other categories of individuals was legitimate: "Who, after all, speaks today of the

33 Richard Goldstone "The Tension between Combating Terrorism and Protecting Civil Liberties" in Richard Ashby Wilson (ed) Human Rights in the 'War on Terror' (Cambridge University Press, Cambridge, 2005) $157,164$.

34 Goldstone, above n 33, 164.

35 Goldstone, above n 33, 165 .

36 Robertson, above n 13, 169.

37 Robertson, above n 13, 169

38 Robertson, above n 13, 182 
annihilation of the Armenians?"39 Moreover, it can lead ethnic communities, exiled leaders or foreign States to take the law into their own hands. A frustrated State might be tempted to send agents to another State without the latter's consent to arrest or assassinate an alleged criminal, hence violating that State's sovereignty and endangering international peace and security. ${ }^{40}$ Finally, prosecution of alleged criminals "ensures maximum visibility, which can have a cathartic effect as regards victims or their relatives." ${ }^{41}$ Holding trials dissipates the drive for revenge and may contribute to the process of reconciliation of society.

Other contributions in that cluster include Carol Greenhouse's review of the effects of the war on terror on the domestic policies of the United States, Spain and Italy. She concludes that "tensions between liberty and security emerge not because they are inherently at odds, but because those terms encode an ongoing competition between central government and ground-level opposition." 42 Neil Hicks echoes this view, following a study of post $9 / 11$ national security laws. He finds that governments, for example Russia, have used it to redefine separatist or nationalist conflicts as episodes of the global war on terror. ${ }^{43}$ Interestingly, not all governments seem to have taken such drastic measures. Richard Falk, a leading expert in international law, compares Spain's conduct to that of the United States and concludes that its experience shows that a tough attitude towards the war on terror does not have to leave human rights as casualties - properly run law enforcement models can work. ${ }^{44} \mathrm{He}$ also deplores the United States' return to the bleak Cold War era type foreign policy of "being with or against us". ${ }^{45}$ David Luban, focusing on civil liberties in the United States, undertakes a systematic destruction of a number of stereotypes and prejudices (he refers to those as fallacies) deriving, according to him, from the wrong question being asked in the first place. The question should not be, he argues, how much liberty can be sacrificed in the name of security, but rather "How much of your own protection against bureaucratic errors or malice by the

39 Louis P Lochner What About Germany? (Dodd, Mead \& Co, New York, 1942) 4.

40 Alberto Costi "Problems with Current International and National Practices Concerning Extraterritorial Abductions" (2003) 9 Revue Juridique Polynésienne 57, 65-67.

41 Antonio Cassese "International Criminal Law" in Malcolm D Evans (ed) International Law (Oxford University Press, Oxford, 2003) 721, 735.

42 Carol J Greenhouse "Nationalizing the Local: Comparative Notes on the Recent Restructuring of Political Space" in Richard Ashby Wilson (ed) Human Rights in the 'War on Terror' (Cambridge University Press, Cambridge, 2005) 184, 204.

43 Neil Hicks "The Impact of Counter Terror on the Promotion and Protection of Human Rights: A Global Perspective" in Richard Ashby Wilson (ed) Human Rights in the 'War on Terror' (Cambridge University Press, Cambridge, 2005) 209, 216.

44 Richard Falk "Human Rights: A Descending Spiral" in Richard Ashby Wilson (ed) Human Rights in the 'War on Terror' (Cambridge University Press, Cambridge, 2005) 225, 236-237. He actually takes the same view about Turkey, a rather dubious proposition considering the record of Turkey on human rights.

45 Falk, above n 44, 237-238. 
government - errors or malice that could land you in jail - are you willing to sacrifice in return for minute increments in security?"46 Trade-offs between security and freedom conceal a number of fallacies. The elimination of those fallacies makes the trade-offs less obvious and less urgent. For instance, he does not understand the plea of emergency. Emergency is a temporary departure from normal conditions and it seems difficult to still be using $9 / 11$ as the triggering mechanism for special powers. ${ }^{47}$ Presumption of guilt, that is, the idea that alleged terrorists do not deserve human rights protection, has been used to deny legal process to Guantanamo detainees, yet the United States Supreme Court has clearly stated its disapproval of the conduct of the Bush administration in that respect. ${ }^{48}$ Finally, he sounds a warning shot at what he calls the militarisation of civilian life, that is, the deference on military matters to the executive, for instance the determination of the status of "enemy combatant". Hamdi $v$ Rumsfeld rebuffed the argument partially ${ }^{49}$ and it is important to distinguish between the President's formal war powers and military expertise. He concludes that military necessity trumps concern for civil liberties and that we should be vigilant against specious claims of military necessity in everyday life. ${ }^{50}$ This cluster is completed by a case study highlighting the threat to privacy inherent in governmental initiatives to gather intelligence. Martha Minnow and Peter Galison examine a project of the United States Department of Defense called the Terrorist Information Awareness Project. ${ }^{51}$ Their conclusions will shock even those most sceptical of government conspiracy theories.

The final cluster gathers three contributions that aim at bringing the debate on terrorism back to the basics. In the late 1990s, debates raged regarding the "absolute versus relative" character of human rights. We also saw the emergence of the concept of human security and globalisation as crucial in empowering civil society. The last three contributors attempt to restart these debates in the particular context of the war on terror. Wiktor Osiatynski reiterates what has always been the majority position in the human rights movement. While it is hard to achieve a cross-cultural consensus about the underlying bases of human rights, no one really doubts that there are a number

46 David Luban "Eight Fallacies About Liberty and Security" in Richard Ashby Wilson (ed) Human Rights in the 'War on Terror' (Cambridge University Press, Cambridge, 2005) 242, 256.

47 Luban, above n 46, 249.

48 Luban, above n 46, 252-253; Rasulv Bush, above n 6.

50 Luban, above n 46, 255-256.

51 Peter Galison and Martha Minow "Our Privacy, Ourselves in the Age of Technological Intrusions" in Richard Ashby Wilson (ed) Human Rights in the 'War on Terror' (Cambridge University Press, Cambridge, 2005) 258. The Terrorist Information Awareness Project "developed advanced informational technology tools to use domestic and foreign databases ... in order to search for 'patterns that are related to predicted terrorist activities'" (at 261). 
of fundamental rights for which there is universal recognition. ${ }^{52}$ His idea that time is ripe for new covenants listing prohibited State conduct and positive State obligations respectively might be interesting on paper but it is doubtful whether it is practical. ${ }^{53}$ Although it is correct that humanitarian developments have often resulted from fundamental rights abuses, a new instrument introduces the risk that States will use it to weaken rather than strengthen their obligations. If the problems associated with the ratification of the two 1977 Protocols to the Geneva Conventions ${ }^{54}$ or even more recent human rights conferences are anything to go by, prospects for such a new instrument do not look good.

For Mary Robinson, the former UN Commissioner for Human Rights, the threats and challenges that our world faces range from terrorism and weapons of mass destruction to genocide and civil war to extreme poverty, endemic diseases and climate change. All these threats are interlinked and the world needs a comprehensive strategy for dealing with them. ${ }^{55}$ In her view, the strategy, also put forward by the UN Secretary-General more recently, ${ }^{56}$ encapsulates the vision of development, security and human rights as equal and mutually interdependent parts of a seamless whole. ${ }^{57}$ These goals can only be advanced in a world composed of strong sovereign States, States that serve the needs of their peoples and are accountable to them. Moreover, the world needs effective global institutions through which those States can work together and strengthen each other. These

52 Wiktor Osiatynski "Are Human Rights Universal in an Age of Terrorism?" in Richard Ashby Wilson (ed) Human Rights in the 'War on Terror' (Cambridge University Press, Cambridge, 2005) 295, 301. This view is shared in the following chapter by Mary Robinson "Connecting Human Rights, Human Development, and Human Security" in Richard Ashby Wilson (ed) Human Rights in the 'War on Terror' (Cambridge University Press, Cambridge, 2005) 308, 316.

53 Osiatynski, above n 52, 305-306.

54 Protocol No I Additional to the Geneva Conventions of 12 August 1949 relating to the Protection of Victims of International Armed Conflicts (8 June 1977) 1125 UNTS 3; Protocol No II Additional to the Geneva Conventions of 12 August 1949, and relating to the Protection of Victims of Non- International Armed Conflicts (8 June 1977) 1125 UNTS 609. The United States is a party to the Conventions but not to the Protocols, although it recognises Protocol II as desirable and most provisions of Protocol I as reflecting customary international law: see Marco Sassoli "Use and Abuse of the Laws of War in the 'War on Terrorism"' (2004) 22 Law \& Ineq 195, 199.

55 Robinson, above n 52, 310-311.

56 See United Nations Secretary-General "In Larger Freedom: Towards Development, Security and Human Rights for All" (21 March 2005) A/59/2005, para 17: "We will not enjoy security without development, we will not enjoy development without security, and we will not enjoy either without respect for human rights."

57 Robinson, above n 52, 313. See also the report of the Commission on Human Security Human Security Now (UN Publications, New York, 2003), available at <http://www.humansecurity-chs.org > (last accessed 20 September 2006). The Commission on Human Security was set up in 2001 with the support of Japan and in response to the call of the UN Secretary-General for a world "free of want" and "free of fear". The Commission was chaired by Mrs Sadako Ogata (former UN High Commissioner for Refugees) and Professor Amartya Sen (1998 Nobel Economics Prize Laureate). The report reaches the same conclusions. 
institutions, like their member States, must be open, accountable and able to work in creative partnerships with the private sector and civil society organisations. Remarkably, this is one of the few references to the concept of "responsibility to protect", and it comes quite late in the book. Finally, Julie Mertus addresses perhaps the most puzzling question for those of us living outside the United States: why has there not been a more vigorous defence of civil liberties since 9/11? The answer, she tells us, comes down to the dissymmetry between the spread of human rights around the world, especially in the 1990s, by Washington, often as a result of United States-based organisations, and the rather poor understanding of human rights at the domestic level within the United States. Survey figures indicating the limited knowledge of American citizens about human rights are shocking ${ }^{58}$ and she exposes the dilemma many non governmental organisations (NGOs) face in struggling to remain independent, thus forfeiting serious funding opportunities "based on conditions that would potentially violate rights to privacy and free speech." ${ }^{159}$ Add to these reasons the long-standing doctrine of United States exceptionalism, and it is not surprising that only an educated minority is able to discern the subtleties between liberty and security and to question the Bush administration's motives in the war on terror. NGOs might need to bring home the message they have been spreading overseas. Only a society aware of human rights can scrutinize the activities of a government prone to dispense with due process and the rule of law.

It is useful to remind ourselves about the overall objective underlying this book: to understand the implications of the war on terror on basic human rights and to clarify and redefine the role of human rights. Many chapters make for compelling reading by their attempt to devise a new analytical framework to what is in fact an old problem - terrorism. They highlight the failures of the Bush administration, but they also provide solutions to make protection of human rights and civil liberties the basis upon which the United States can really battle terrorists. They address the shortcomings of the international community and propose ways of tackling the problems globally with workable strategies. They evaluate the gaps between liberty and security carved by nebulous concepts and hidden agendas before bridging them by including human rights principles in counterterrorism policies. Some of the contributions, in particular that of Mary Robinson, provide another dimension to the discussion by looking at the problem in terms of human security. The view from civil society is also refreshing.

The editor and the contributors should be commended for their thoughtful analysis of such a controversial and complex subject. The book will make readers think and perhaps inspire them to tackle terrorism without betraying the fundamental values that are the fabric of democratic societies.

58 Julie Mertus "Human Rights and Civil Society in a New Age of American Exceptionalism" in Richard Ashby Wilson (ed) Human Rights in the 'War on Terror' (Cambridge University Press, Cambridge, 2005) 317, 326, where she refers to an Amnesty International survey according to which 94 per cent of American adults are not aware of the Universal Declaration of Human Rights.

59 Mertus, above n 58,329 
This is not to say that the book is perfect. There are a few disturbing trends such as the limited references to international instruments and UN initiatives, showing unfortunately a rather closeminded vision of international law. Some contributors also tend to provide ambiguous conclusions to otherwise valid exposés of law and policy. However, everyone agrees that mistakes have been made in fighting terrorism in the new millennium, the recent United States Supreme Court cases feature prominently and there are calls for guarded optimism for the future. They might be right. After all, the Bush administration has indicated that it is cognisant of some of these errors - for example, the admission in July 2006 by the Pentagon ${ }^{60}$ that detainees held by the United States at Guantanamo Bay and elsewhere around the world would be protected under Common Article Three of the Geneva Conventions. ${ }^{61}$

In concluding his introductory chapter, Wilson argues for the replacement of a "war on terror model" by an enhanced law-enforcement strategy ${ }^{62}$ and calls for the United States to reject the doctrine of "exceptionalism" and take stock of how other parts of the world have dealt with terrorism. ${ }^{63}$ What transcends this book is the suggestion that counter-terror strategies can only work within the framework of international law, with appropriate reform of the relevant institutions, domestic policies respectful of due process and the rule of law, and recognition of the concept of human security.

60 BBC "US detainees to get Geneva rights" (11 July 2006) <http://www.bbc.co.uk> (last accessed 10 September 2006)

61 Convention (I) for the Amelioration of the Condition of the Wounded and Sick in Armed Forces in the Field (12 August 1949) 75 UNTS 31; Convention (II) for the Amelioration of the Condition of the Wounded, Sick and Shipwrecked Members of Armed Forces at Sea (12 August 1949) 75 UNTS 85; Convention (III) relative to the Treatment of Prisoners of War (12 August 1949) 75 UNTS 135; Convention (IV) relative to the Protection of Civilian Persons in Time of War (12 August 1949) 75 UNTS 287.

62 Wilson, above n 7, 29-30

63 Wilson, above n 7, 31-33. 